\title{
The Evolution of Transcendence
}

\author{
Gregory Gorelik ${ }^{1}$
}

Published online: 1 June 2016

(C) Springer International Publishing 2016

\begin{abstract}
The transcendent experience, often described as an ego-dissolving encounter with something greater than one's self, is cross-cultural and pan-historical. I present a model describing the evolution and function of various evolved modes of transcendence, such as group-directed transcendence, theory of mind (ToM)-evoking transcendence, aesthetic transcendence, and epistemic transcendence. I then discuss the vulnerability of these modes of transcendence to costly exploitation by selfish individuals who activate the transcendent state in others for their own reproductive benefit. In the ensuing section, I discuss the relationship between transcendence and human development across the lifespan, and conclude with some thoughts on the epistemic and ethical utility of transcendence.
\end{abstract}

Keywords Transcendence $\cdot$ Evolution · Spirituality . Mysticism $\cdot$ Exploitation $\cdot$ Evolution of religion

The transcendent experience is marked by a subsumption of the individual self in an all-encompassing reality. The boundary between the self and the outside world is broken and a more expansive perspective diffuses throughout all aspects of one's experience. All the while, the self fizzles out and gets replaced by something greater than one's self. Such experiences are often accompanied by the revelation of some heretofore hidden, inexpressible truth communicated by a higher intelligence or allpervading sentience. Although the previous statements may sound like wishy-washy, New Age platitudes, the scientific

Gregory Gorelik

gregory.gorelik33@gmail.com

1 Austin, TX, USA study of mystical states lends credence to at least some of these experiences. More than $30 \%$ of American and British respondents, including $25 \%$ of atheists and agnostics, reported having at least one transcendent experience (cited in Levin and Steele 2005). Likewise, research on patients with epilepsy and on Buddhist monks mid-meditation highlights the role of the brain in the production of mystical and transcendent states (Davidson and Lutz 2008; Waxman and Geschwind 1975). Of course, we need not refer to neuroscience to know that physiological processes are responsible for the induction of transcendence- and all other psychological states, for that matter. Drugs and sleep deprivation, for instance, can trigger illuminative out-of-body experiences and hallucinatory visions (Babkoff et al. 1989; Wilkins et al. 2011).

Two points, in particular, are elucidated by such phenomena. The first is that a naturalistic explanation is fully compatible with the spiritual dimension of life. The fact that mystical states can be linked to the firing of electrical impulses and to the action of neurotransmitters on neural receptors demonstrates the inseparability of the transcendent state from material reality. At the very least, we can say that certain aspects of the transcendent experience can be explained in naturalistic terms. Of course, as William James cautioned, even if the brain and human physiology are responsible for religious experiences, the positive and meaningful effects of such states should not be discounted (James 2004/1902, pp. 15-34). Indeed, romantic love can just as easily be traced to such physiological processes as the firing of dopamine and oxytocin and the immunohistocompatibility of lovers (Liu and Wang 2003; Wedekind et al. 1995), yet love is made no less real or meaningful thereby.

The second point that is illustrated by the linkage of transcendent experiences with brain states is that these experiences are the products of evolution. Even if such experiences are aberrations of normal psychological functioning, there 
have to be normally functioning neural structures in place that such states are aberrations of - structures with a long history of evolution by natural and sexual selection. This point highlights one of the basic tenets of evolutionary biology - namely, that phenotypic traits need not be wholly adaptive in an evolutionary sense (in that they always contribute to successful survival and reproduction), but may consist of nonadaptive by-products of adaptations. There could be much within the transcendent experience that is associated with such non-adaptive by-products, including the belief in gods and disembodied spirits. Nevertheless, as discussed in what follows, some transcendent experiences may carry survival and reproductive value. A less acknowledged possibility is that the capacity for transcendent experiences in some is parasitized by others who seek to selfishly exploit it. Such exploitation, I argue, is adaptive for those who benefit off of others' delusions and self-destructive devotion to religious and political causes.

\section{Definitions}

When discussing matters of religion or transcendence, ambiguity and obfuscation are typical pitfalls. Whether religious or secular, everyone has their own view of what religion is, often focusing on this or that feature to the exclusion of all others. Some stress the rituals, taboos, communal ceremonies, and feelings of belongingness that religions engender (Ginges et al. 2009; Sosis and Bressler 2003). Others view specific beliefs and dogmas about the supernatural as the linchpins of religious observance (Harris et al. 2009). Similarly, "transcendence" can refer to a feeling of connectedness with one's environment and the beings inhabiting it, to one or another New Age belief about spiritual communion, or to meditationor drug-induced mental travel to other dimensions and realities. Words like "spiritual" and "mystical" often motivate similar disagreements.

Though every word has strengths and weaknesses, some words and definitions are better suited to my purpose in this article than others. By "religion," I mean the union of culturespecific ideas and beliefs about the supernatural world with specific rituals and rules for regulating behavior. I will interchangeably use the words "transcendent," "spiritual," and "mystical" to refer to the human experience of interconnectedness, the perceived dissolving of boundaries between individuals and their environments, and the dissolution of one's sense of "self" - each of which may be described as an experience of being interconnected and indistinguishable from something greater than one's self. As subsequently discussed, transcendence states are states of high emotional and cognitive arousal experienced as one or all of the following: ingroupdirected transcendence, theory of mind (ToM)-evoking transcendence, aesthetic transcendence, and epistemic transcendence. Although transcendent experiences are included among some of the most potent emotions and cognitive states that motivate religion, without specific culturally inherited, community-wide beliefs, and rituals associated with the supernatural, they cannot be classified as religions.

Note that transcendent experiences do not always involve the supernatural world, as suggested by the creative power of transcendent revelations in art, literature, science, and sport. Likewise, religious beliefs and theological doctrines are often divorced from transcendent states. Religion and transcendence should therefore be viewed as overlapping, though not necessarily congruent, phenomena. Note, however, that I will occasionally submit to past authors' use of "religious" as being synonymous with "transcendent," a use that is best exemplified by William James's Varieties of Religious Experience. I hope that the context of the discussion will make the distinction between transcendent and religious phenomena clear.

\section{Circumscription of the Topic}

The "father of American psychology," William James, is popularly known for his influential series of lectures on peak religious states, released in book form as The Varieties of Religious Experience (James 2004/1902) ${ }^{1}$. James's prescient ideas placed the study of religion on a naturalistic, psychological foundation. James's Varieties was also unrivaled for its collection of first-person accounts of religious experiences, such as those of Teresa of Avila and Leo Tolstoy. Aldous Huxley's Perennial Philosophy (1970/1945) likewise addressed the cross-cultural and pan-historical nature of transcendence. According to both scholars, the common core of such experiences is one's complete immersion in something much larger and greater than one's self. This entity is variously referred to as "God," "the Tao," "nothingness," "the Godhead, " and "the Ground of all existence" and is often described as transcending space and time; and is experienced alongside a dissolution of one's ordinary sense of self, or ego. Quoting St. Paul, James describes such an encounter in its Christian guise: "I live, yet not I, but Christ liveth in me. Only when I become as nothing can God enter in and no difference between his life and mine remain outstanding" (James 2004/1902, p. 362, emphasis mine). James likewise relates the poet J. A. Symonds' somewhat more anxious mystical experience:

It consisted in a gradual but swiftly progressive obliteration of space, time, sensation, and the multitudinous factors of experience which seem to qualify what we are pleased to call our Self. In proportion as these

\footnotetext{
${ }^{1}$ I respectfully burrow the title for this section from William James's title to the second chapter of The Varieties of Religious Experience (James 2004/1902).
} 
conditions of ordinary consciousness were subtracted, the sense of an underlying or essential consciousness acquired intensity. At last nothing remained but a pure, absolute, abstract Self. (p. 333)

Likewise, Huxley (1970/1945), describing what is shared by many of the world's faiths, writes:

For, as all exponents of the Perennial Philosophy have constantly insisted, man's obsessive consciousness of, and insistence on being, a separate self is the final and most formidable obstacle to the unitive knowledge of God. To be a self is, for them, the original sin, and to die to self, in feeling, will and intellect, is the final and all inclusive virtue. (p. 36)

Anticipating Csikszentmihalyi's concept of "flow," an experience of selfless enjoyment elicited by tasks whose demands are great enough to challenge an individual without being too overbearing (Csikszentmihalyi and Nakamura 2002), James quotes Starbuck, who writes:

An athlete ... sometimes awakens suddenly to an understanding of the fine points of the game and to a real enjoyment of it, just as the convert awakens to an appreciation of religion. If he keeps on engaging in the sport, there may come a day when all at once the game plays itself through him — when he loses himself in some great contest. In the same way, a musician may suddenly reach a point at which pleasure in the technique of the art entirely falls away, and in some moment of inspiration he becomes the instrument through which music flows. (p. 185)

Starbuck's description of peak experiences underscores the fact that transcendent states need not be couched in religious concepts or language, and that individuals may experience secular forms of ecstasy wherein the experience of "something greater" may allude to an athletic contest or a piece of music.

Accounts of transcendence-inducing communal rituals from Western and Eastern cultures - from the Eleusinian mysteries in ancient Greece, to the ecstasies of Sufi mystics, swirling dervishes, and Buddhist monks - also attest to the universality of mystical and transcendent states across societies and historical periods. Traditional Sub-Saharan, Siberian, and Mesoamerican cultures have been described as often revolving around shamans, who, with the aid of drumming, dancing, and drugs, induce a hypnotic mindset through which group members commune with departed ancestors, spirits, and gods (Atran 2002, p. 124; Pinchbeck 2002; RapinskyNaxon 1993; Waida 1983). An illustrative example comes from the induction of hallucinogenic states by Amazonian shamans via ayahuasca (Rivier and Lindgren 1972).
Ayahuasca, a potent hallucinogen derived from a combination of rainforest plants, induces visions of spiritual realms beyond ordinary reality. The shamanic tradition has been practiced for millennia, and may be the precursor to modern religious institutions. This is suggested by the way that traditional societies use shamanism to intercede in the spiritual realm in order to aid in daily activities such as hunting, ritualistic healing, and the servicing of the dead and dying (Rapinsky-Naxon 1993).

Mystical traditions within organized religion have flourished since the inception of the religions themselves, be it the Gnostic movement in early Christianity or the yogic movement in Hinduism. Modernity, however, has somewhat severed the bond between religion and mysticism. In part, this is due to the increasing secularization ushered in by the Enlightenment and its advances in scientific and philosophical discovery. Yet, the uneven retreat of religious parochialism did not diminish the yearning for the transcendent. Much of this yearning, however, has often regressed into the world of supernaturalism and the wishful thinking of self-help movements. James noted the late nineteenth-century rise of what we now refer to as the "New Age" movement in his discussion of the "Mind-cure" movement, which, according to James (writing at the turn of the last century), "... has reached the stage, for example when the demand for its literature is great enough for insincere stuff, mechanically produced for the market, to be to a certain extent supplied by publishers" (James 2004/1902, p. 91). A more apt description of some of the selfhelp and popular psychology literature of today cannot be found.

Although there may be a place for psychedelics in inducing valuable mystical states that are unencumbered by superstition (see the ensuing discussion of the self-transcending effects of psilocybin), the excesses of the 1960s and 1970s drug movement have likewise been counterproductive to a scientific study of transcendence and to the role of psychedelics in transcendent experiences. The reasons for this are twofold: (1) the drug movement's overreliance on instant enlightenment (e.g., "Turn on, tune in, drop out"), often at the cost of evidencebased rationality and physical and psychological health, and (2) the subsequent "war on drugs" that this movement engendered. It is only recently that scientists have begun to break out of the legal and social shackles of this ongoing war, as evidenced by the increasing scientific attention to the salutary effects of psychedelics on everything from PTSD to end-oflife care (Grob et al. 2011; Oehen et al. 2013). There is also mounting attention to the issue of transcendence from both a secular, scientific perspective and as a matter of personal fulfillment outside of the supernaturalism-steeped traditions of organized religion and New Age spiritualism. These trends are evident in the rise of "neurotheology," a variegated attempt at tracking the neurophysiology of spiritual experiences (see Davidson and Lutz 2008), and the popularization of secular books and lectures on mindfulness and areligious spirituality 
(e.g., Harris 2014). All of these attempts are welcome and necessary, but the increasing popularity of mindfulness risks outpacing the evidence for its efficacy and transforming it into another self-help consumer fad plagued by magical thinking. Furthermore, a scientific account of transcendence is incomplete if it is restricted to only studying its proximate workings and effects without a deeper exploration of its distal, evolutionary origins. The present article, albeit not unprecedented, is my contribution to this more distal-level understanding of transcendence. Of course, however conscious they may be of the dynamics and personal meaning of their transcendent states, individuals are probably unaware of the evolutionary antecedents of their transcendence, especially if they have not been educated in evolutionary principles. For example, individuals may be aware of an emotional closeness to others following a transcendent communal ritual, but unaware of the selective advantage of this emotion across evolutionary history.

\section{The Evolutionary Underpinnings of Transcendence}

Although preliminary, the following model may be useful in capturing some of the necessary features of transcendence. Specifically, I posit that the transcendent experience is marked by either one or all of the following evolved psychological processes: group-directed affection (often involving feelings of unity and camaraderie), the perceived presence of incorporeal minds and supernatural agents, a feeling of awe following an encounter with something beautiful and grand, and an epistemic state that is associated with the revelation of some hidden reality or deeper truth. Although the different modes of transcendence are more-or-less distinguishable, this model is mostly agnostic as to the anatomical, physiological, and cognitive underpinnings of transcendence (though plausible neurocognitive mechanisms associated with epistemic transcendence are discussed). Different modes of transcendence may share overlapping cognitive systems and, conversely, similar modes of transcendence (e.g., group-oriented transcendence) may emanate from cognitive systems that differ across contexts (e.g., transcendence in an intimate environment surrounded by a few close friends versus communal transcendence in a large crowd). Also note that the psychological mechanisms underlying transcendence may have evolved for other purposes, with transcendence being either a nonadaptive by-product or a co-opted adaptation.

\section{Group-Directed Transcendence}

Group-directed transcendent experiences rely on cognitive and emotional systems whose simultaneous activation by the various features of a communal ritual uniquely defines a type of transcendent experience. The social nature of the communal setting and the often-reported feelings of empathy and a dissolving of boundaries between oneself and one's fellow tribe members or co-worshippers serve the proposed function of consolidating coalitional ties among group members - a function that is aided by cognitive states associated with love, friendship, and camaraderie (for review, see Atran 2002, pp. 149-173 and Sosis and Alcorta 2003). The social nature of religious cognition is likewise observable at the level of the brain, as suggested by Kapogiannis et al.'s (2009) finding of a correspondence between certain types of religiosity and the cortical thickness of brain areas implicated in social cognition. Some evolutionary theorists propose that such evoked social bonding benefits groups over individuals (Wilson 2002), whereas others contend that the benefit is to individuals and their genes (Cronk 1994). Assuming that one's participation in such rituals has the effect of garnering support and cooperation from one's fellow group members, the psychological capacity for taking part in and signaling one's commitment to others during such rituals can benefit individuals, their genes, and, as a by-product, their groups.

Regardless of whether the reproductive benefits of transcendent rituals are enjoyed by individuals or groups, the theory of costly signaling can explain the level of emotional investment that is expected from participants (Atran 2002, pp. 127-140; Ginges et al. 2009; Sosis and Bressler 2003; Zahavi 1975). According to costly signaling theory, organisms are under selection pressure to honestly communicate their ability and willingness to apportion benefits to other organisms. Assuming that ancestral humans were less likely to cooperate with potential cheaters (i.e., those who would accept the benefits of group membership without paying the costs), it would be to an individual's advantage to send an honest signal of cooperativeness in order to attract other cooperators. In order to be believed, however, an organism's brandishing of such signals must be costly in terms of physiological recourses, time, or vulnerability to harm or death. Cheaters are deterred from brandishing such costly signals, and so can be effectively excluded from cooperative coalitions. An example of such costly signaling is gift giving and generosity between group members, which was taken to an extreme by some Northwestern Native American tribes who threw "potlatches," or grand feasts wherein hosting chiefs would destroy all of their leftovers in order to signal their bountiful resources and largesse (Barnett 1938).

More pertinent to the current discussion, an individual might signal his cooperative and group-oriented qualities by exhibiting a costly emotional response that is hard to fake by cheaters. Life history milestones such as puberty-related coming-of-age ceremonies and the cementing of pairbonding with communal wedding rituals often rely on participants' abilities to exhibit hard-to-fake emotional responses appropriate for the occasion (i.e., a solemn and mature commitment to one's role as an adult within one's community and 
an unmistakable show of sexual and emotional fidelity to one's future spouse, respectively). Evolutionary psychologists have also proposed that grief exhibited by friends and family of the deceased functions to communicate a mourner's value as a potential social partner to onlookers (Winegard et al. 2014). Indeed, in addition to its effect on recruiting future allies, such emotional costs may simply function as an emotional debt paid by the aggrieved to the deceased - a necessary payment whose initial promise functioned as a costly signal of commitment to the now-deceased while he or she was still alive. Such costly emotional signaling was probably more frequent in ancestral tribal societies that engaged in communal rituals in order to control everything from the weather to success in intertribal warfare. Even in the secular, urban environments of today, adherents of some religious traditions (e.g., Pentecostal Christians, Hassidic Jews) continue to come together for energy- and emotion-consuming communal prayers and feasts.

Rituals are especially potent in unifying group members via behavioral synchrony and shared emotional resonance. Anthropologists have documented the universality of tribal practices such as drumming, chanting, and dancing during religious rituals - practices that are either explicitly or implicitly enacted within the group for cohesion-building purposes (Atran 2002, pp. 171-172; for a separate discussion of music as an activator of transcendence, see "Aesthetic Transcendence" section in the present article). Drumming, chanting, and dancing all produce rhythm-based behavioral synchrony among participants - an evolved capacity whose proposed selected function is the building and strengthening of social ties (Lakin et al. 2003). Indeed, mother-child synchrony is associated with a host of positive personal and social outcomes in childhood and adolescence (Criss et al. 2003; Feldman 2007; Feldman and Greenbaum 1997; Feldman et al. 1999). Lending support to its proposed evolutionary role in enacting adaptive social interactions, adults often mimic attractive opposite sex confederates-i.e., men mimic physically attractive women, whereas women mimic high-status men (van Straaten et al. 2008). Is such mimicry successful in furthering adaptive social interactions? Indeed, mimicry is an effective cohesion-building tool, as highlighted by participants' greater liking for confederates who mimicked their body movements and men's increased romantic interest in confederate females who mimicked them during a speeddating scenario (Chartrand and Bargh 1999; Gueguen 2009).

The "social glue" function of behavioral synchrony (Lakin et al. 2003) probably evolved as a mechanism that promoted such dyadic interactions but was co-opted for more large-scale cooperation necessary for survival in our ancestral past. It is this behavioral synchrony that promotes the transcendent experience of identifying one's self with an enlarged collective of ingroup members in lieu of one's usually more circumscribed identity. The practical benefit of such surface- level behavioral synchrony is the emotional "attunement" (Atran 2002, p. 172) necessary for the successful completion of collective tasks (e.g., foraging, warfare, etc.). Thus, the transcendence induced by behavioral synchrony may simultaneously serve as both, a costly signal of commitment to one's ingroup, and the very means by which this commitment is realized. However, a prolonged, synchrony-inducing ritual does not always deliver any immediate benefits, and its attendant time and energy costs only signal participants' future commitment to one another. In a subsequent section, I will discuss how the human propensity to mimic and be mimicked by others is vulnerable to hijacking by manipulators during the transcendent state.

\section{Theory of Mind and Transcendence}

As powerful as the commitment-oriented emotions are, Pentecostal revivals replete with snake handling and echolalia, and even solitary experiences of supernatural entities, activate additional psychological states. In his discussion of the nature of beliefs, David Hume (1978/1739) proposed that ideas become beliefs via, among other influences, the passions and the emotions. Specifically, an idea becomes "lively" (i.e., gains "belief" status) if it is given force by direct experience, the imagination, or the passions. Hume specifically mentions religion's ability to stir up passions such as fear and terror, and indeed, writes that " $\ldots$ in matters of religion men take a pleasure in being terrify'd ..." (p. 115). That men take pleasure in being "terrify' $d$ " is even highlighted by quite secular activities such as reading Stephen King novels and watching horror films. The activation of fear during moments of transcendence is discussed in anthropological literature on coming-of-age rituals wherein the juvenile or adolescent must withstand some torturous trial, vision quest, or painful ordeal (e.g., genital mutilation-see Wilson 2008) in order to become an adult member of the tribe. One Amazonian tribe stipulates that, to become warriors, coming-of-age boys must endure the wearing of a glove made of vegetation and studded with viciously biting "bullet ants" as part of a communal milestone-marking ceremony (Botelho and Weigel 2011). Often, such ceremony-induced emotional states are wedded to specific religious beliefs and dogmas about the supernatural world and its inhabitants, which, in accordance with Hume, are reified into truth-status.

Bullet ants aside, fear is often elicited solely by the specific content of a religious or cultural tradition's message. Often, the content will include reference to supernatural entities with their own minds, intentions, judgments, and powers of influence. An evolved system variously referred to as the "agency detector," the "intentional stance," and the "theory of mind" (ToM) is evoked during the processing of such supernatural content (Baron-Cohen 2005; Baron-Cohen et al. 1985; Dennett 1987). All of these describe mechanisms whose 
evolved function is the ready attribution of animacy to unknown sounds, sights, and sensations, the by-product of which is the occasional error of perceiving something inanimate as something animate. It is thought that by erring on the side of assuming that a rustling in the bushes, a shadowy movement in the grass, or an unexpected tingling on one's skin is, in fact, a predator, human ancestors ensured their own survival and reproduction (Barrett 2000; Haselton and Buss 2000). Such sounds and sights were usually benign, but in case they were not, the immediate triggering of the fight-or-flight response would have saved an early human from an early grave.

Albeit possessing the same properties as other mechanisms whose function is the detection of animate beings, theory of mind (ToM) specifically refers to the attribution of human psychological properties to other entities. It is likely that, in addition to predators such as poisonous snakes and spiders and the big cats of the savanna, ancestral humans often had to contend with other humans for resources and mates, and that such conflicts were often deadly. Thus, some of our ancestors' most dangerous predators, and most potent allies, were other humans whose intentions had to be intuited in order to predict whether these other humans' behavior posed a threat or an opportunity for cooperation. The human propensity to anthropomorphize (i.e., to readily attribute emotions and thoughts to non-human entities such as dogs, cats, clouds, and gods) may stem from this easily activated ToM. When a god's or spirit's characteristics are predatory (characteristics perhaps associated with a demonic god or spirit), the contemplative reacts with fear and terror-correlates of the fight-orflight response. This may lead to bargaining with the god or spirit, or rationalizing one's behavior to the god or spirit in order to avoid punishment. In addition to being predatory, deities and demons may be associated with prey. Although direct representation of gods as prey animals is rare, the anthropological literature on hunter gatherers depicts a prevalence of cultures with "animal guardian" spirits who must be propitiated with offerings and sacrifices in exchange for an auspicious hunt (Brown 2005).

Note that predators and prey are not the only stimuli that activate agency attribution mechanisms such as ToM. As we mature, our social world gradually expands from the immediate circle of our parents, to include other adult caregivers, siblings, friends, and lovers. In Totem and Taboo, Freud (1919) posited that the human belief in God is associated with the image of the "primordial father," a figure eliciting both feelings of childhood attachment and the Oedipal fear of being castrated. Although there is no evidence of any primal father template or its attendant fear of castration, Freud's conflation of deities with parental figures gains traction from studies by Kirkpatrick on the relationship between the attachment system and beliefs in the supernatural (Kirkpatrick 2005). According to Kirkpatrick, the attachment system - a naturally selected system whose function is the formation of life-sustaining bonds between offspring and caregivers - is activated by beliefs in supernatural agents and incorporeal entities. Granqvist and Kirkpatrick (2004) present evidence that children's attachment styles toward parentswhether secure or insecure - are carried over to their relationships with culturally inherited figures such as gods.

As discussed by Wright (2009) and Norenzayan et al. (2016), the invention of agriculture led to a gradual, if uneven, rise of ever-more powerful and all-knowing deities who were especially concerned with human moral conduct-a process that finally culminated in monotheism. The increased production and storage of harvests demanded a population-wide system of morality that promoted cooperation, labor division, and the reduction of stealing and free riding. The cultural invention of gods and goddesses with parental qualities can help to sustain such a moral system. Parental deities are compelling and memorable because they induce the same fear, guilt, and love that a parent would induce, in addition to counterintuitive properties such as omnipotence, omnipresence, and omniscience. "Minimally counterintuitive" concepts are memorable precisely because they draw on readily available cognitive schemas (e.g., "mother," "father," "parent," etc.) while including an unexpected and unique violation of category membership (e.g., "can listen to one's thoughts" or "is bodiless") (for a summary of research on the durability of minimally counterintuitive beliefs, see Atran 2002, pp. 100-107, and Barrett 2000). The punishing and rewarding properties of such supernatural agents are what helped sustain cooperation within growing ancestral populations of genetically unrelated individuals who, in turn, acquired the status of fictive kin. Especially in the Christian tradition (wherein kinship terms are used to describe one's relationship with the divine, as in "God the Father" in relation to His "children," who are all "brethren"), transcendent states typified by filial piety are quite common. Sosis and Bressler's (2003) study of nineteenth-century American communes supports the view that, when wedded to costly religious rituals, supernatural beings maintain group cooperation and longevity.

In light of Kirkpatrick's own research (Kirkpatrick and Shaver 1992), and the preponderance of various fertility gods and goddesses across different times and places, it is possible that human attachments to lovers and spouses might likewise function as templates for beliefs in deities with sexual and erotic properties. This is attested to by the Tantric discipline in Hinduism, which advocates the cultivation of union with the divine godhead, or "Brahman," via sexual intercourse. Note that Tantric sexual practices involve more than just lustful effervescence; rather, they are marked by an infusion of emotions associated with romantic love in addition to sexuality. As described by Borchert (1994), Tantric practices encourage lovers to view one another as "... keys to each other's welfare, for each is a god in the other. Each loves the other 
within themselves" (p. 90). Again, experiences of selfnegation and the acceptance of a reconstituted sense of self - a unifying feature of transcendent states - are evident in such moments of romantic ecstasy. In this case, rather than embodying the larger spirit of the group, as is the case in group-oriented transcendence, the reconstituted sense of self includes one's lover or is a unitary combination of the two lovers within a single persona that is "greater than one's self." Similar portrayals of the divine as an object of romantic desire are found in Judeo-Christian and Islamic writings, such as the Bible's Song of Songs and the poetry of Jalāl ad-Dīn Muhammad Rūmī.

Tantric practices and some Western accounts of transcendence (such as the orgasmic ecstasy of Teresa of Avila ${ }^{2}$ ) suggest that transcendence may occur alongside the activation of oxytocin-mediated psychological circuits whose evolutionary function is the cementing of romantic commitment to mates (Liu and Wang 2003). Such mechanisms enabled our male and female ancestors to cement their unions to one another in order to ensure mutual investment in the resultant offspring, and are perhaps activated when ToM templates associated with lovers or objects of romantic desire are co-opted by concepts of incorporeal entities such as gods or spirits. Further evidence for the activation of these mechanisms during moments of transcendence comes from late medieval and early modern accounts of sexualized unions with Christ (as well as an assortment of angelic and demonic figures) experienced by Catholic nuns in the thralls of orgasmic ecstasy (Sluhovsky 2002). Such instances of religion-inspired sexual hysteria spread across Europe in a pandemic fashion, as convent after convent was exposed to rumors of these spectacles. It is possible that the advent of erotic expressions of love for the divine gave those who took on vows of celibacy the plausible deniability necessary to express their earthly needs and desires in religiously sanctioned ways. Because most of these religious enthusiasts were women, their expressions of erotic attachments to Christ probably included romantic sentiment in addition to carnal desire (reflecting ancestral women's greater obligatory investment in offspring and the ensuing evolution of preferences for long-term over short-term mates; Trivers 1972).

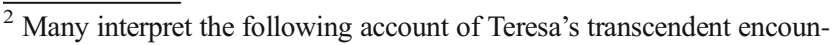
ter with an angel in explicitly sexual terms: "I saw in his hand a long spear of gold, and at the iron's point there seemed to be a little fire. He appeared to me to be thrusting it at times into my heart, and to pierce my very entrails; when he drew it out, he seemed to draw them out also, and to leave me all on fire with a great love of God. The pain was so great, that it made me moan; and yet so surpassing was the sweetness of this excessive pain, that I could not wish to be rid of it. The soul is satisfied now with nothing less than God. The pain is not bodily, but spiritual; though the body has its share in it, even a large one. It is a caressing of love so sweet which now takes place between the soul and God, that I pray God of His goodness to make him experience it who may think that I am lying" (Teresa of Avila 1904, pp. 156-157).
}

\section{Aesthetic Transcendence}

Who can deny the loss of self that occurs when one is captured by the variegated colors of a sunset, the reveries brought on by a song, or the human universality depicted in a play or movie? In instances of aesthetic transcendence, the dissolution of the self is accompanied by an expansive sense of balance, symmetry, grace, and style that is greater than one's self. Notwithstanding the adage "Beauty is in the eye of the beholder," there are certain evolved, universal criteria that people and objects must exhibit if they are to be judged beautiful. The transcendent experience of beauty is ultimately rooted in the experience of pleasure-and for good reason. Evolutionarily, pleasurable feelings are associated with survival and reproduction, whereas painful feelings are associated with harm and death. Despite people finding beauty in horror and pain, aesthetic sensations are usually associated with pleasure. (Indeed, part of the aesthetic experience of horror and pain may be the relief one experiences once such terror subsides after the movie credits roll or the horror novel is laid on the nightstand).

In general, people find landscapes beautiful if they resemble the savannas of our hominin ancestors - e.g., open spaces with adequate tree cover, footpaths for navigation, and the presence of animals and vegetation for foraging (Dutton 2003). Likewise, faces that exhibit symmetry, averageness, and smoothness of skin - signals of genetic health and parasite resistance - are judged to be more beautiful than faces that do not exhibit these features (Apicella et al. 2007; Fink et al. 2001; Gangestad et al. 1994). We also find stories told by engaging orators to be aesthetically pleasing because such stories relayed evolutionarily relevant information to our ancestors-e.g., how to successfully hunt down a gazelle or avoid being outwitted by a rival (Pinker 1997, pp. 541-543). The pleasure associated with such sources of beauty draws us to environments and organisms that would have promoted ancestral survival and reproduction. When an individual looks at an attractive face or a vibrant sunset, for example, his or her opioid- and dopamine-mediated pleasure circuits are activated (see Chelnokova et al. 2014, and Salimpoor et al. 2011, for the effects of attractive faces and beautiful music on these circuits). Thus, the pleasure associated with beauty functions to direct individuals to aspects of their environments that were ancestrally associated with various reproductive benefits, be they healthy and fertile mates, hospitable landscapes, or lifesaving information relayed as poetry or oratory.

In addition to landscapes, beautiful faces, and engaging stories (e.g., the picturesque setting of houses of worship, the beauty of religious figures in sculptures and paintings, and the appeal of biblical tales and life-affirming sermons), the transcendent experience of beauty is inspired by something that is grand and mysterious - something that invites further exploration. The human propensity to appreciate the 
aesthetic qualities of even some inhospitable environments (e.g., the open ocean, deserts, glaciers, or the surface of Mars) suggests that aesthetic pleasure inspires curiosity and exploration - aspects of the human experience that have been historically associated with the discovery of new lands, untapped resources, and, in the intellectual sphere, heretofore unknown or unacknowledged scientific paradigms and findings. Evolutionarily, such beauty is associated with the pleasure of exploring an object or environment that may possess opportunities for survival and reproduction - e.g., a new tool that may yield more resources or an unexplored glade that may be teeming with nutritive plants and animals. No doubt, being open to new experiences is often dangerous, if not deadly; contacting other tribes in order to acquire their unique toolmaking skills or traversing a strange path potentially teeming with predators are decisions that our ancestors could not afford to make regularly. This is why, in addition to being compelled by the awe-inspiring beauty of forbidden landscapes, humans are sometimes inhibited by emotions such as fear. Grand and imposing gothic cathedrals may call forth such aesthetic experiences by simultaneously activating the sense of mystery and opportunity alongside fear of the unknown. The aesthetic pleasure of such fear may lie in the relief one feels when the pleasure-inducing aspects of the aesthetic experience take over-e.g., the safety and orderliness of divine protection, the opportunity of heretofore unexplored spiritual realms.

Music The unique power of music to elicit transcendence in individuals and groups deserves special attention. Some scholars claim that music is nothing but an evolutionary byproduct or "cheesecake" of the mind-i.e., it is pleasurable simply because it exploits the normally adaptive pleasure circuits associated with language and other auditory faculties (Pinker 1997, pp. 534-535). Others believe that music production and appreciation are sexually selected evolutionary adaptations (Miller 2000). Still, others contend that, because music has the universal effect of inducing pleasure and of bringing people together via this shared pleasure, its main function is in uniting group members in mutually benefitting alliances (Huron 2001). As with most complex and multifaceted human phenomena, music may consist of a combination of various adaptive and non-adaptive features.

Rhythm is the most basic component of music and its importance to humans may be a product of a long evolutionary history alongside rhythmical sounds and sensations associated with breathing, walking, and the beating of the heart. Moving to the same rhythm also elicits emotional closeness between listeners (Launay et al. 2014), suggesting an adaptive role of rhythmical timekeeping in establishing mutually cooperative bonds between group members. Furthermore, the production and perception of music stimulates many of the same brain areas that are involved in the production and perception of speech (Levitin and Menon 2003). Indeed, as with much else, James presaged this link between music and speech by noting that certain "chords" are stirred within us "which music and language touch in common" (James 2004/1902, p. 364). This may be the reason why music has such an emotionally stirring effect on people. That is, when you strip away the vocabulary, grammar, and semantics of verbal communication but leave (and exaggerate) the nonverbal syntax and intonations of speech (i.e., the time-based structure of patterned sound, the alternating rise and fall of verbal pitch), what is left is the emotion-inducing melodic core that lies at the heart of human conversation. Musicians skillfully exploit this core whenever they construct melodies whose differentially embedded patterns evoke emotional intonations associated with various speech sounds, be it the sounds of happiness, sadness, anger, sexual and romantic interest, or, if there are such sounds, the sounds of transcendence. When performed in the context of a religious ritual, music has the power to elicit multiple modes of transcendence simultaneously via group-solidifying synchrony, reference to supernatural agents, and the experience of beauty associated with temporal symmetry and nonverbal emotionality. As cited by Atran (2002, p. 171), one survey found that music was the most common elicitor of religious experiences, outranking prayer, religious service attendance, Bible reading, and being alone in church. As James put it, "Music gives us ontological messages which non-musical criticism is unable to contradict, though it may laugh at our foolishness in minding them" (James 2004/1902, p. 364).

\section{Epistemic Transcendence}

Such musically elicited ontological messages speak to another significant feature of some forms of ecstatic and transcendent experiences: their perceived truth value. For those who have them, these experiences of illumination and enlightenment are in a different epistemic category than everyday encounters with people, places, and objects. Epistemic forms of transcendence such as these are marked by the feeling that some fundamental truth or revelation was glimpsed, and such experiences are often followed by a change in the seer's perspective on life and the nature of reality [see James (2004/1902) discussion of the "practical fruits" of religious experience, pp. 230-286]. It is likely that humans possess an evolved psychological system devoted to truth seeking. Although there are arguments that support the existence of evolved self-deceptive mechanisms (von Hippel and Trivers 2011) and the withholding of accurate information by some psychological systems from others (Kurzban 2010), an accurate accounting of the world is often necessary for successful survival and reproduction. This entails that, given enough exposure to contrary 
information, humans are capable of changing their minds and adopting beliefs that they previously opposed or were not exposed to (see Vallacher and Wegner 2012, p. 344, on "catastrophic shifts" in social cognition).

The volatile physical and social environments of our ancestors likely selected for learning mechanisms capable of recognizing and overcoming past mistakes and creating associations that were more reflective of reality. Neurocognitive research points to a specific brain mechanism that may be responsible for such tracking of one's own and of others' mistakes: the anterior cingulate cortex. When an individual makes a mistake on a cognitive task (e.g., he or she reads the word "blue" rather than correctly naming the color of its ink, which is red), the anterior cingulate cortex is activated (Pardo et al. 1990). Its activation ensures that such mistakes are minimized in the future, and indeed, tasks that are associated with conflicting responses trigger the anterior cingulate cortex in anticipation of the possibility of making a mistake (Carter et al. 1998). The complement to such error-finding processes is a system that ensures that accurate knowledge structures are built via associative learning mechanisms. Such a creative process is necessary if humans are to perfect the skills and develop the knowledge base necessary for the fast and efficient completion of long-term tasks.

Although the development of such knowledge structures is an everyday occurrence, remembering where one misplaced one's keys or learning something new about the tax code is unlikely to lead to any major overhauls in one's cognitive universe. The formation of pervasive truth-carrying knowledge structures associated with the transcendent experience relies on additional factors. One such factor is the unification of disparate perceptions, memories, beliefs, and motivational systems via the recognition of some common pattern among them. Transcendent experiences associated with such representational overhauls are a reflection of the moment-tomoment change from one semantic paradigm or perspective to another. Indeed, the transcendent experience is often described as an event during which an individual uncovers something heretofore hidden, or makes connections among heretofore unrelated aspects of one's personal or intellectual life. Writing of the unification of the "divided self," James states that "[i]t may come gradually, or it may occur abruptly; it may come through altered feelings, or through altered powers of action; or it may come through new intellectual insights, or through experiences which we shall later have to designate as 'mystical"' (James 2004/1902, p. 159). The occurrence of such experiences also highlights the commonalities between the supernaturalism-steeped illuminative experiences of mystics and the moments of inspiration associated with artistic and scientific breakthroughs.

As documented by neuroscientists and psychologists, integration of neural and cognitive function occurs at all levels of cognition, from the local (such as the integration of various systems devoted to the unitive experience of vision), to the global (such as the integration of visual with auditory, tactile, gustatory, and olfactory systems, and the psychological integration of various personality characteristics, selfconcepts, and schemas) (Varela et al. 2001; Lewkowicz and Ghazanfar 2009; Vallacher 2009). Indeed, adaptive behavior would not be possible if some type of psychological integration did not exist. The act of reproduction, for example, requires functional integration of visual, auditory, olfactory, kinesthetic, tactile, and other sensory, cognitive, and affective systems.

Although all such processes of informational synthesis speak to their adaptive design, knowledge structures are not always reflective of the true state of the world. Even from an evolutionary perspective, the acquisition of survival-unrelated knowledge, such as a Bible verse or a Shakespearean sonnet, may be adaptive if it merely leads to an increase in attractiveness to members of the opposite sex. Furthermore, although the human capacity to acquire, analyze, and sometimes synthesize disparate types of information is very much a product of selection, the continuously changing content that is processed by these knowledge acquisition mechanisms may be divorced from concerns about survival, reproduction, or truth.

To summarize, epistemic forms of transcendence are, what I believe, instances of cognitive synthesis; that is, heretofore dissociated knowledge structures become associated and a new perspective develops. Physiologically, such neuronal associations probably form via synaptic strengthening. The experience of synthesis that such associations produce can be induced by the ingestion of various psychotropic substances. Müller and Schumann (2011) even proposed that the harvesting and use of psychotropic plants by humans is an example of coevolved mutualism, and that one of the benefits of such coevolution is the formation of new knowledge structures from pre-existing ones. If the new knowledge structures aid the individual in survival or reproduction, the drug-taking behavior gets naturally selected.

Although it is intriguing to consider that the benefits of mind-alteration for early humans may have led to our coevolutionary dependence on various psychotropic organisms, such experiences as just described also occur during normal states of consciousness. The rewarding aspects of knowledge acquisition, in particular, ensure that humans are continuously motivated - probably via dopamine, a neurotransmitter likewise associated with synaptic strengthening (Kulisevsky et al. 2009; Otmakhova and Lisman 1996)_to seek out new knowledge or to reassess existing knowledge structures. When new knowledge is acquired, or a common pattern is detected among unrelated memories, ideas, or experiences, the motivating and rewarding aspects of dopamine ensure that we continue to engage in such knowledge acquisition and processing in the future. In the environments of our ancestors, 
such cognitive development within one's lifetime perhaps aided our ancestors in building tools, controlling fires, and domesticating plants and animals. No doubt, humans have unique genetic and cultural inheritances that we do not share with our cousins, the chimpanzees. But reaping the fruit of such genetic and cultural gifts requires both development and learning within a lifetime. Even if agriculture is mostly a product of cultural imitation, there had to have been a moment (or many moments) now and in our evolutionary past when the cognitive connection between the concept of seeds and their ability to give rise to edible plants was made.

I am not suggesting that the creation of rewarding knowledge is alone responsible for the ecstasies of certain transcendent states, but the gaining of some deeper insight is a recurring theme in descriptions of transcendent states and peak experiences. Most likely, the more immersive forms of transcendence - what Aldous Huxley, echoing Eckhart's use of "intellect," refers to as "immediate intuition" (1970/1945, p. 133) - involve the activation of ToM processes alongside the knowledge-creating mechanisms just mentioned - a cognitive state that is felt as a reception of some divine truth or a glimpse of some hidden realm controlled by a hyper-intelligent mind. However, the immersive aspects of such experiences need not rely only on the activation of various cognitive systems. For example, the selective deactivation of the default mode network-a brain structure that is implicated in one's sense of self, or one's identification as a separate and unique beinghas been observed in fMRI scans of psilocybin-ingesting participants (Carhart-Harris et al. 2012). Incidentally, peak performance experiences referred to as flow states (Csikszentmihalyi and Nakamura 2002), and the oftenreported "ego-death" experienced by meditators and psychedelics users (Leary et al. 2000/1964), all involve the loss of self-consciousness and the dissolution of one's sense of separateness from one's environment and its inhabitants. When individuals who are in such states of self-dissolution also experience the creation of knowledge or the linkage of heretofore unconnected knowledge structures, the experience may become immersive and enlightening.

More work is needed in tracking the nature of transcendent states. As suggested by the previous discussion of the various modes of transcendence, there is probably no such thing as the exemplar case of transcendence. Some transcendent experiences may be activated by the social sphere and its attendant affiliative emotions which ensure commitment to the ingroup. Others may be under the influence of culture-specific supernatural beliefs and the fear- and love-inducing properties of gods and spirits. Still, others may be anchored in the immersive aspects of beauty and knowledge synthesis, and the ecstasies they unleash. More likely than not, many instances of transcendence involve the activation of a combination of psychological systems, and the unique and personal nature of transcendence may reflect this unique pattern of activation that varies within an individual's lifetime and from one individual to another. Added to this is the very real possibility that there are a lot more contexts, psychological systems, and experiences of transcendence that are still undiscovered. No doubt, I have left out many known and still unknown modes of transcendence. It is my intention that, in the future, scholars and scientists formulate a more complete taxonomy of the different types of transcendence, their activating cues, their neurocognitive signatures, their complex interactions, and their evolutionary origins. Perhaps the formulation of such a taxonomy might itself be a product of the transcendent acquisition and synthesis of knowledge by scholars and scientists from across the disciplinary spectrum.

\section{The Exploitation of Transcendence}

The signaling of costly emotional commitment to the ingroup during communal transcendence probably serves the adaptive function of cementing coalitional ties to one's fellow group members. Somewhat more questionable is whether any of the other modes of transcendence are adaptive, be it for genes, individuals, or groups. It is plausible that ToM-mediated transcendence ensures the survival of coalitions by invoking supernatural beings that regulate behavior within the group, but this could very well be a by-product of the human tendency to project sentience where there is none. Likewise, even if aesthetic and epistemic transcendent states guide individuals toward survival- and reproduction-enhancing opportunities, the costs of being incapacitated by such all-consuming experiences may outweigh their adaptive benefits. As I will elaborate in this section, the propensity for transcendence may be taken advantage of by those who would elicit it in others in order to benefit themselves. In such instances, the exploitation of transcendence may very well become a naturally selected strategy for manipulators (I use "manipulators," "exploiters," and "cheaters" interchangeably to refer to those who parasitize others' transcendent states) even if victims' transcendent states are non-adaptive by-products of other psychological adaptations.

Note that, albeit grounded in research, I include some speculations that might open up avenues for further theoretical and empirical exploration. Also note that I will primarily focus on exploitation-i.e., parasitic forms of transcendence induction in others. It is plausible that there are instances of individuals activating the transcendent state in one another as a way of enacting mutually benefiting reciprocal interactions. My focus on the exploitative aspects of transcendence induction is intended to contrast with its benign depictions in popular culture such as New Age literature and pop psychology. Among scholars, historians, and mystics from both Eastern and Western 
traditions, there is an acknowledgment that transcendent states can be horrifying and even disastrous. What St. John of the Cross referred to as "the dark night of the soul," often described as a bleak and meaningless void left in the wake of transcendent and mystical states, is only now being given scientific consideration (Rocha 2014). Note, however, that somber and even depressive states can be adaptive for the individuals experiencing them, as research on depression's energy-conserving and social-reassessment functions suggests (Keller and Nesse 2006). Conversely, being under the spell of someone maleficent does not necessarily have to be horrifying to be reproductively costly; indeed, one would expect exploiters to have evolved the ability to elicit seemingly positive affective states in others as a disarming maneuver.

Some religious mythologies actually highlight the possibility of spiritual deception and exploitation. During his meditative retirement under the Bodhi tree, for example, the Buddha was said to have been tempted away from enlightenment by the demon Māra and his three daughters-Tanhā (Craving), Arati (Boredom), and Ragā (Lechery) (Guruge 1997). Likewise, during Christ's 40day and 40-night fast in the desert (note that fasting, among other bodily mortifications, may bring forth hallucinatory visions and other transcendent experiences), Satan tempted Christ with the prospect of relieving his hunger, manifesting his (i.e., Christ's) power, and obtaining power over every kingdom in the world-all of which Christ refused (Luke 4: 1-13; Matthew 4: 111). The fact that various strains of mainstream Buddhism and Christianity acknowledge that even the founders of their respective religions may have been exposed to illusory spiritual experiences points to the ever present danger of being deceived or exploited during one's personal journey of transcendence.

Of course, this begs the question of who benefits from the exploitation. Dawkins' concept of the "extended phenotype" (Dawkins 1982) captures the relevant biological features of the exploitation of transcendent states (for an earlier description of religious exploitation as extended phenotypic manipulation, see Cronk 1994). ${ }^{3}$ The extended phenotype refers to all of the adaptive effects that an organism exhibits outside of its physical body. For example, a virus that manipulates its host to engage in bouts of sneezing and coughing while around other potential hosts is using the host as an extended phenotype of itself. More specifically, some of the virus's genes-i.e., the genes that

\footnotetext{
${ }^{3}$ Although Odling-Smee et al.'s (2003) concept of "niche construction" has been proposed as an alternative to the extended phenotype, in that it better captures the feedback of environmental manipulation on the subsequent evolution of organisms (Wells 2015), its conceptual broadness will limit my ability to hone in on the victims - i.e., extended phenotypes - of such manipulation.
}

contributed to the coughing and sneezing of hosts-were selected across generations because they helped to build widely dispersed extended phenotypic webs of virulence that enabled the replication of those very genes. Like viral genes, some human genes may have been selected because they contributed to our ancestors' development of extended phenotypic uses of environments and the beings inhabiting them-whether mutualistically or parasitically. I posit that many human experiences are mediated by extended phenotypic phenomena between humans and other humans, including transcendent experiences.

Dawkins' (1976) sister concept of the "meme" suggests that memes (or units of cultural evolution) may benefit from the induction of transcendence without the necessary presence of a human exploiter. That is, much like genes replicate themselves by enabling their phenotypes' survival and reproduction, religious rituals, doctrines, and ideas induce transcendence in human minds as a way of replicating themselves in the meme pool (i.e., the cultural analog to the gene pool). Although this is plausible, the amorphous nature of the meme and its relative lack of replicative fidelity (Atran 2002, pp. 236-262) cast doubt on its suitability as a potential locus of evolved exploitation. In any case, even if units of culture are capable of inducing transcendence and benefiting from the said induction, human exploiters' indisputable presence in the marketplace of religion and spirituality limits my current focus to the parasitic effects of humans on one another.

\section{Exploitation of Group-Directed Transcendence}

Individuals may unwittingly enact group-benefiting behaviors spurred on by the transcendent experience if they are manipulated into doing so by fake commitment signals from cheaters. One such exploitative strategy involves the brandishing of supernormal stimuli-i.e., stimuli that exaggerate the evolved features of normally subdued communicative signals (Dawkins and Krebs 1979). So, for example, the parasitic cuckoo-i.e., a bird that parasitizes parents from other species-exaggerates the red mouth and unique soliciting vocalization of the young of its foster parents in order to acquire provisioning. Similarly, shamans and preachers may enact repetitive and elaborate rituals and emotions whose purpose is to alter the behavior of ritual participants and congregants (Cronk 1994; Sosis and Alcorta 2003). Although such costly signals may function as honest expressions of ingroup commitment rather than exploitative supernormal stimuli, given the historic and current preponderance of religious manipulation, it is possible that costly commitment signals are sometimes repurposed for deception and exploitation. Although a costly signal's main function is to send an honest signal of one's status or intention (if it 
were not costly, cheaters would be able to easily fake high status or cooperative intentions), the evolutionarily recent emergence of religious rituals and emotions suggests that their costs may not yet be great enough to deter cheaters from enacting the rituals and emotions in question. Indeed, the continuously improving ability of cheaters to mimic costly signals is what is responsible for the evolution of even costlier honest signals, suggesting that the evolution of unforgeable religious signals is still (and perhaps always will be) a work in progress.

Emotions often trigger behaviors, just as behaviors trigger emotions. For example, liking someone predisposes an individual to act in a friendly manner toward the liked person-e.g., laughing at the person's jokes, mimicking the person's body movements and mannerisms, etc. Conversely, when one's behavior is being mimicked, one unconsciously begins to like and feel an emotional closeness to the mimicking person (Chartrand and Bargh 1999). As discussed, mimicry and behavioral synchrony are evolved mechanisms whose selected purpose is to enable smooth social interaction and to communicate one's affiliative intentions toward others. The ready activation of this set of mechanisms in social situations is more or less an automatic response. Therefore, it should not be so reproductively costly to mimic others in order to get them to like you and to confer benefits on you-even if you do not intend to benefit them in turn. In effect, what one is doing when one mimics another for one's own selfish benefit is entraining the manipulated person's behavior to be an extension of one's own behavior-that is, mimicry is used to employ others as extended phenotypes. The loss of one's sense of personal identity, the disappearance of boundaries between oneself and others, and the alignment of one's own interests with the interests of another individual, group, or greater entity - commonly reported experiences of transcendence-perhaps describe the psychological experience of being someone else's extended phenotype.

Exploitative shamans-figures who are already venerated within the community-can enhance the tribe's commitments to the shaman's own selfish interests by simply engaging the tribe in synchronous dancing and chanting. Such exploitation can have devastating consequences for the tribe if the ceremony encourages an attack on a neighboring tribe when such an attack is less than optimal for the tribe, but beneficial for the shaman (e.g., if it enables him to monopolize the tribe's women when the men go off to war). As proposed by MacNeill (2004), one of the main evolved functions of the religious experience is the arousal of a bellicose feeling and a propensity to sacrifice for the ingroup during battle. Although MacNeill's account of transcendence may be a bit too limited in scope, soldiers have indeed been known to lose themselves in the heat of war, often experiencing something akin to spiritual transcendence. ${ }^{4}$ One is no longer a separate entity but part of a larger body that includes one's fellow brothers-inarms for whom one is ready to sacrifice one's life. The effect of synchrony on the subsumption of the self into the larger military unit is likewise manifest in military drills and processions. What makes this form of exploitation so insidious is that simple, low-level synchronous movements can bring about transcendent states that are then used to inspire deadly intergroup aggression or selfrighteous vengeance against purported transgressors within the group.

As discussed, mimicry and behavioral synchrony are ubiquitous in both tribal ceremonies and modern religious services. Hunter gatherers often dance and chant in unison during communal gatherings. The beating of the drums and the rhythmicity of the chanting set the pace for the congruous motions of all involved. Often under the tempo set by the shaman, participants jump in unison, land in unison, and vocalize in unison - behaviors that, no doubt, arouse a unifying feeling among the participating tribe members. Likewise, Orthodox Jewish services are marked by both improvised and ritualized swaying and bowing, and Muslim services are highly ritualized and ordered with respect to the exact timing of prostrations. All such examples of patterned synchrony suggest that, even if leaders and ritual participants have differing reproductive interests, their mutual suspicions may subside as they mirror one another's actions and emotions.

\section{Exploitation of Theory of Mind}

Belief in omniscient and omnipotent deities activates either approach or avoidance systems and their attendant emotions-e.g., hope when believers are promised earthly or heavenly rewards for following a god's directives, and fear of hellfire and other celestial punishments for transgressions. In either scenario, beliefs in supernatural agents are elicited by individuals or social groups in order to guide the behavior of others who accept such beliefs. Collective beliefs in non-

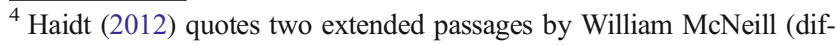
ferent from Allen MacNeill, cited in text), a WWII veteran, that are illustrative of such transcendent experiences during warfare. The first reads thus: "Words are inadequate to describe the emotion aroused by the prolonged movement in unison that drilling involved. A sense of pervasive well-being is what I recall; more specifically, a strange sense of personal enlargement; a sort of swelling out, becoming bigger than life, thanks to participation in collective ritual." McNeill quotes another veteran: "Many veterans who are honest with themselves will admit, I believe, that the experience of communal effort in battle ... has been the high point of their lives .... Their 'I' passes insensibly into a 'we,' 'my' becomes 'our,' and individual fate loses its central importance .... I believe that it is nothing less than the assurance of immortality that makes self sacrifice at these moments so relatively easy .... I may fall, but I do not die, for that which is real in me goes forward and lives on in the comrades for whom I gave up my life" (pp. 221-222).
} 
existent supernatural agents may be benign or even beneficial if they help individuals and group members solidify long-term reciprocal coalitions via both the threat of punishment and the promise of reward. However, when victims' communal emotions are simultaneously activated alongside their personal fears and desires (e.g., the fear of illness, the desire for wealth, etc.), supernatural threats and incentives can be especially potent in transforming these victims into the extended phenotypes of manipulators. The fact that supernatural beings are unfalsifiable (see Sosis and Alcorta 2003, on how unfalsifiable postulates are more "stable referents" for groups than falsifiable postulates) ensures that their ability to motivateand exploit-human behavior remains unquestioned. Although being motivated by the intentions of supernatural agents does not necessarily depend on experiencing transcendent states, the felt presence of supernatural minds during moments of transcendence gives these supernatural minds staying power in the minds of individuals undergoing transcendence.

That religious rules and dogmas are used to control social behavior and individual thought is hard to deny. Just focusing on the three main monotheistic religions of today, each includes a cannon filled with specific injunctions and rules of conduct, including mores for cleanliness, sexual behavior, religious rites, and injunctions to believe specific narratives about the world and its relationship with the supernatural. According to Cosmides and Tooby's (1992) definition of a "cheater" as someone who receives benefits without paying the stipulated costs, individuals who use the threat of divine punishment or the incentive of divine reward to accrue benefits from others without themselves following the divine injunctions are glaring examples of such cheaters. Although research is lacking on which supernatural characteristics cheaters are more likely to invoke when manipulating others, the previously mentioned characteristics associated with predatory, parental, and amorous gods suggest a few that may be of interest. For example, the capacity for predators and parents to inspire fear of either death or parental punishment might be more useful to manipulators who want to deter victims from engaging in certain behaviors. Conversely, the capacity for parents and lovers to confer benefits might be invoked by manipulators when used to entice victims toward behaviors that benefit manipulators at a cost to victims.

The role of parental deities as tools of manipulation is especially relevant in contexts of sudden religious conversionan empirical indicator of a transcendent experience. In their meta-analysis, Granqvist and Kirkpatrick (2004) found that individuals with insecure attachments to parents were much more likely to experience sudden religious conversions. Given the ubiquity of stress, anxiety, and emotional vulnerability prior to the onset of an intense religious or mystical experience (often experienced by adolescents and individuals on the margins of society; for a review, see Atran 2002, pp. 166-169), it is plausible that manipulators specifically exploit such vulnerability and insecure parental attachment by presenting victims with a surrogate supernatural parent within the context of an emotionally charged transcendent experience.

Faith healers and cult leaders similarly prey on the vulnerable by invoking various supernatural beings. The faith healing preacher Peter Popoff ${ }^{5}$ - famously exposed by James Randi for claiming to divine his congregants' personal details while actually getting this information from his wife via a radio transmitter - employed this very tactic by invoking God and the Devil during his transcendence-inducing faith healing services. The dual strategy of promising the benefit of miraculous healing and - albeit somewhat more subtlyreminding congregants of the ever-present costs of hellfire is evident from these pronouncements to a woman with stomach cancer: "Are you ready for God to burn that cancer out?" This was followed by Popoff's laying of his left hand on the woman's forehead and screaming "Back off Devil!"- - which caused the woman to reel to the ground in ecstasy. The danger of believing and trusting in faith healers like Popoff are evident when individuals forego medical treatment in favor of divine cures. Cult leaders such as Jim Jones, David Koresh, and Warren Jeffs relied on similar invocations of both divine and infernal powers to exploit their parishioners out of their belongings, sexual autonomy, and, in the case of Jones and Koresh, their lives.

\section{Exploitation of Aesthetic Transcendence}

As discussed by Austin (1980), the religious experience and the aesthetic experience have much in common; both trigger similar types of knowledge, both promote a similar process of self-unification and integration, and both motivate moral behavior (though unspecified by Austin, such behavior may be related to ingroup cooperation). These similarities between religious and aesthetic experiences probably involve some of the same cognitive processes discussed in the present article. Austin believes that, at bottom, the religious experience and the aesthetic experience are the same, though outfitted with different cultural accoutrements - presumably doctrine and group-commitment in the case of the former, and traditions of creative expression in the case of the latter. Indeed, from church choirs to the Christianity-inspired paintings of Dali, there is often no clear division between the clergyman's transcendence and the artist's. What was left unspecified in Austin's account was the distinction between the origin of the transcendent state in the producer of art and in its consumer. It is here that I include manipulative religious individuals alongside artists. Specifically, the transcendent experience of the shaman or priest, like the transcendent experience of the painter or composer, gives form to either a sermon or some

\footnotetext{
${ }^{5} \mathrm{https}: / /$ www.youtube.com/watch?v=q7BQKu0YP8Y
} 
public act of devotion, which, in turn, arouses the transcendent state in the parishioner. So, in the case of both religious and artistic transcendence, the transcendent state in the producer of the religious expression or artwork is communicated to the consumer of the religious or artistic message via the medium of the message itself.

In addition to activating the same pleasure circuits activated by evolutionarily relevant stimuli such as livable landscapes, fertile mates, and life-saving information, art's appeal lies in what it communicates about the artist. According to sexual selection theory (Darwin 2006/1871), what evolves is not just what benefits survival (natural selection), but also what benefits reproduction (sexual selection). Specifically, individuals who are especially good at creating complex and aesthetically pleasing signals may be communicating their high intelligence, deft hand-eye coordination, and successful control of resources - traits that would benefit the offspring of whomever chose them as mates. In this way, creativity and artistry are considered "sexy" and are thereby multiplied in a population across evolutionary time. The sway of a charismatic preacher's sermon is much the same - both the preacher and the artist rely on their transcendence-inspired productions in order to manipulate the reactions and behavior of those who admire the productions. In the case of sexually selected capacities for transcendence, the observer's focus is on the mateworthiness of the creator of the religious or aesthetic production (the very individual with whom such transcendence is shared) rather than just the creation itself. Thus, an artist's reproductive value is judged by the degree to which he or she can induce aesthetic transcendence in the consumer of the artwork. It is a topic for future study whether, and to what extent, successful preachers and artists rely on the aesthetic induction of transcendence in order to garner fertile mates, devoted flocks, and dedicated followers.

Part of what makes someone an exceptional exploiter of other individuals and groups is the ability to make others passionately acquiesce to manipulation. For this task, several avenues are at the manipulator's disposal. Religious and political ceremonies that involve drugs, passionate oratory, music, dancing, and other modes of transcendence elicitation, may function as venues for social integration, and sometimes, exploitation. Hitler, for example, perfected his theatrical gestures by practicing them while listening to recordings of his own speeches (Newton 2014), suggesting an explicit awareness of the manipulative power of body language and aesthetically pleasing oratory. The use of music and visual propaganda by totalitarian regimes and despots suggests that aesthetic transcendence is useful in politics, not just art and religion. Most of the time, music listening is innocuous, and possibly even physically, psychologically, and socially beneficial. However, it is not hard to find examples of when music can function as a manipulative ploy that exploits individuals and crowds. The most obvious example entails the use of music during military parades and processions. At such gatherings, music is known to arouse feelings of jingoistic fervor and emotional commitment to one's country and its armed forces. As the orchestra plays the bombastic sounds of a military march, missiles and artillery are proudly displayed in front of the gawking eyes of entranced citizens (as well as ally and enemy nations) who are inspired and frightened by such a show of military might. Calling this type of music use "exploitative" may be a misnomer, assuming that civilians and military officers are often supporting their own interests by supporting the military interests of their nations. Music may be exploitative, however, when its production is intended to elicit a costly emotional response in listeners, as would occur when populaces are manipulated into supporting doomed and self-destructive military campaigns by the propagandistic sounds of national anthems and jingoistic war songs. In this way, religious and nationalistic feeling (often the most lethal in combination) may be musically elicited by religious and political leaders whose aim is the extended phenotypic use of crowds and populations.

The use of music in religious settings is effective in inspiring collective bouts of devotion and transcendent personal experiences, often interpreted in supernatural terms. However, we do not have to go to a religious service for firsthand knowledge of the emotionally stirring effects of music; instances of collective deindividuation and violent mob behavior at musical events, such as the breakdown of social order at the Woodstock festival in 1999 (Wyman 1999), highlight the manipulative effects of music on behavior in more secular contexts. That music is emotionally poignant, and yet, nonverbal, may explain its cross-cultural appeal and communicative value. Alas, this nonverbal structure of music may be associated with various social costs, in that it is much more difficult to scrutinize a message that is nonverbal than one which relies on words. The rhythms, harmonies, and melodies produced by instrumental musicians, for instance, are rarely (if ever) assessed for their truth value (if there is such a thing), while the stump speeches and debate responses of politicians are analyzed and re-analyzed by political pundits on $24-\mathrm{h}$ news networks.

Music is not the only tool that religions employ to avoid suspicions of illegitimacy on the part of congregants. Another one entails the use of human language - though not the kind that is understood by congregants. Examples of this phenomenon include Orthodox Jewish services, which are rife with ancient Hebrew praying and chanting (often quite rhythmical and melodic); the Catholic Mass, which partly attains its mystical aura from the recital of ancient Latin passages (passages whose translation was expressly forbidden by the hierarchy of the Catholic Church throughout the Middle Ages); and the recitation of the Koran in Arabic (a language that many Muslims in Pakistan have no knowledge of). It is difficult to scrutinize millennia-old passages written in languages that no 
one understands save for religious leaders (and often, they do not understand them themselves). Though a religious message may be false, it may acquire gravity and reverberation by the aesthetically pleasing manner of its deliverance. Over time, its influence is enhanced as generation supplants generation and augments the manipulative effectiveness of its intonationsan instance of cumulative cultural evolution (see Caldwell and Millen 2008).

\section{Exploitation of Epistemic Transcendence}

Aesthetic appeal may not be sufficient for a manipulator to circumvent the skepticism of would-be extended phenotypes. Better if a manipulator uses both aesthetic and epistemic states to manipulate a victim. However shaky on empirical grounds, the elegance and symmetry of Buddhist concepts such as reincarnation and dependent origination provide aesthetically pleasing - and transcendence-inducing — states of knowledge. As previously discussed, humans are equipped with specialized cognitive mechanisms whose naturally selected function is the acquisition of knowledge relevant to survival and reproduction. Many times, such knowledge is self-generated, as when individuals figure things out on their own. Other times, knowledge is proffered by supposed experts, be they experts in practical or in spiritual matters. The benefits to the receiver of the spiritual message sent out by the sender may come in the form of ingroup-directed affection, which may be useful in generating mutual cooperation. There are, however, cases of religious authorities who have issued transcendence-inducing knowledge at a cost to receivers of that knowledge.

Similar to the aforementioned warmongering shaman who takes advantage of the tribe's women while the men are away at battle, it is possible that religious authorities in twentiethcentury Japan (e.g., Kitarō Nishida and D. T. Suzuki, among others) evoked transcendent states in Japanese troops with various intellectual influences associated with Zen Buddhism (see Sharf 1993). This is not to say that these authorities were consciously malevolent or manipulative, but their effect on the martial mindset of the Japanese was quite tangible. The epistemic effect of Zen thought (discussed in this section) was greatly aided by the activation of emotional commitments to the Japanese nation and subordination to its emperor. When wedded to Zen self-negation, the kin-directed traditions of Shinto and the communal traditions of Buddhism helped to motivate individuals' willingness to sacrifice themselves for the nation and the emperor during war. Especially for the more educated students who were enlisted in the WWII effort, the influence of Zen intellectual propaganda was a key component in the creation of a psychological mindset aimed at complete self-negation (Harding 2014). Albeit proving to be a useless wartime strategy, such self-negation was perhaps instrumental in motivating many of the suicidal kamikaze pilots.
In order to elucidate the manipulative use of knowledge in eliciting and exploiting the transcendent states of victims, we must first understand the signals that manipulators are sending that are picked up by the learning mechanisms of victims. Second, we must track the neurocognitive progress of such input stimuli through the victims' minds. Finally, we must account for the behavioral output on the part of victimsoutput which harms victims but benefits manipulators. Albeit speculative, I believe that something like the ensuing account of the exploitation of transcendence by Zen teaching may explain the effect of epistemic transcendence on selfsacrifice during war.

First, I begin by examining one aspect of the midtwentieth-century Zen message ${ }^{6}:$ "absolute nothingness" (Harding 2014; Sharf 1993). As with Buddhism, more generally, the negation of the self is considered a necessary precondition for the attainment of Nirvana. Indeed, much of Buddhist meditative practice is centered on the cultivation of selflessness and the realization of one's true "Buddha nature." Zen kōans (i.e., short, traditional stories and aphorisms whose vocalization is thought to bring about realization and enlightenment) were perhaps instrumental in fostering such selflessness. Two of the most famous kōans, for example, ask "What was your original face before father and mother were born?" and "What is the sound of one hand clapping?" (Hori 2004). Though meaningless and unanswerable, the intent of the kōans is for the practitioner to realize the true nature of the self-specifically, that there is no self to begin with. The seeming absurdity of both questions perhaps points one to the realization that there is no such thing as an original face or the sound of one hand clapping. Rather, in place of an "original face," there are only historical contingencies that precede, co-occur with, and follow one's mortal sojourn in this life. Likewise, one's existence is impossible but for the interdependent factors that create it-i.e., the two hands necessary to create the clapping sound. Although these interpretations are admittedly speculative, the traditional goal of kōan recitation is apparently to make the subject indistinguishable from the object-more specifically, the distinction between the practitioner who is uttering the kōan and the kōan itself should fall away.

Esoteric interpretations of Zen practices aside, it is hard to deny the pervasive pattern of self-negation - be it in Zen Buddhism or suicidal jihadism - across religious traditions. This brings me to the second stage of understanding the effects of such selflessness-inducing messages: their neurocognitive journey in the minds of receivers. In order for selflessness to

\footnotetext{
${ }^{6}$ Note that critics have questioned the link between traditional Zen teachings and the more Western, militaristic, and colonial face of Zen following the Meiji Restoration of the late nineteenth century (Sharf 1993). However, as with the "no true Scotsman" fallacy, Zen's newfound nationalism and militarism became central to its identity in wartime Japan, making it difficult to distinguish "true" from "false" Zen.
} 
occur, there has to be some anatomical and physiological network in the brain that is associated with the concept of self. Neuroscientists have inadvertently stumbled onto such a network by tracking subjects' brains between experimental tasks - that is, when subjects were not doing anything. This network they termed the "default mode network" (DMN) "default" because it appeared to be the baseline network to which the activity of subjects' brains usually reverted (Buckner et al. 2008). Further studies revealed that the DMN is activated whenever subjects are reflecting on themselves and when their minds are "wandering." A study on the effects of psilocybin (the active molecule in psychedelic mushrooms) on participants' brains revealed that the more immersive - and, presumably, more selfless - aspects of the drug state were associated with decreased activation of the DMN (Carhart-Harris et al. 2012). The DMN is present in other primates, from macaques to chimpanzees, and appears to also activate primates' social-cognition areas (Mars et al. 2012). This suggests that one's ability to create a self-image is dependent on one's relationship to one's fellow group members (see Meltzoff and Decety 2003, on imitation's role in children's apprehension of others' minds prior to their own). Indeed, evolutionarily, a social primate's ability to monitor whether others are friends or enemies, reciprocators or moochers, depends on these others' relationship to the selfi.e., are they friends with $m e$ ? Do they owe me anything? The enhanced capacity for humans to monitor their relationships with others over long tracks of time may explain the emergence of the "narrative self," or a self that weaves together all of one's episodic memories in a sequential pattern, and imagines future memories that might be incorporated into the same pattern (Suddendorf and Corballis 2007). Evolutionarily, such narration enabled humans to pursue personal long-term goals, work toward imagined outcomes that were desired, and avoid imagined outcomes that were not desired.

The final stage of my analysis concerns the effect of selflessness-producing epistemic messages on receivers' behavior. When the DMN, and whatever other structures associated with the narrative self, are selectively deactivated during a transcendent state, the individual loses sight of his or her own personal goals, concerns, and distinctions, and the only thing that exists is the present moment. It is at such a time that the individual becomes vulnerable to other internal and external influences, be they helpful or harmful. Although it is possible that the selective deactivation of the DMN may be physically and psychologically beneficial (as is suggested by research on meditation's ability to improve concentration; Davidson and Lutz 2008), the loss of self may come at a cost. If one such cost is falling prey to the manipulative signals of religious and political authorities, then the inculcation of selflessness may be a powerful means by which said authorities ensure a steady supply of extended phenotypes with which to procure resources and fight wars. Activating psychological mechanisms devoted to ingroup commitment or commitment to one's leaders (see Haidt's 2012, discussion of the evolved systems of deference to one's ingroup and its authorities, or what he terms the "Loyalty/Betrayal" and "Authority/ Subversion" foundations of morality, respectively) while deactivating the DMN may explain how some religious messages compel individuals to engage in violent self-sacrifice on behalf of some group- or leader-benefitting cause.

Again, I should note that it is often difficult to distinguish between whether the individual undergoing transcendence is harmed, benefited, or unaffected by the transcendent experience. Likewise, the individuals sending such transcendenceinducing messages (e.g., either in the form of an intellectual exercise such as a kōan or chanted passages from the Koran) may not necessarily be reproductively benefited by such signaling. Using the Dalai Lama as nothing more than a hypothetical example, according to a 2012 Telegraph article, an 18year-old Tibetan monk immolated himself to death in commemoration of the 53rd year since the Chinese government ousted the Dalai Lama from Tibet (Staff 2012). Beijing's claim that the Dalai Lama condones such suicidal statements may be borne out by the Dalai Lama's own reaction: according to The Telegraph, "The Dalai Lama has said he does not encourage the protests, but he has praised the courage of those who engage in self-immolation and has attributed the protests to what he calls China's 'cultural genocide' in Tibet." Ignoring the Dalai Lama's doublespeak of not "encouraging" and yet praising the "courage" of self-immolating monks, the Dalai Lama's statement might motivate future bouts of selfimmolation by rewarding such behaviors with ingroup recognition and spiritual advancement. Exploitative or otherwise, the self-sacrifice of monks on behalf of the loss of a historical homeland does not necessarily garner reproductive benefits for the Dalai Lama, given the Dalai Lama's celibacy (discounting, of course, any reproductive benefits to his family members or any non-reproductive political benefits, such as a free Tibet).

\section{Transcendence and Development}

The previous discussion of the evolved modes of transcendence may imply they are either fully functional early in development or that they are equally likely to be activated during the entirety of a person's lifespan. Both of these suppositions are questionable. In an evolutionary reworking of Maslow's hierarchy of needs, Kenrick and Griskevicius (2013) amended Maslow's famous developmental pyramid to more accurately reflect the emergence of adaptations that satisfy the biological needs of the individual. Whereas Maslow's pyramid reaches its apex at "self-actualization" (i.e., the development of creativity, spontaneity, and moral sense), Kenrick and Griskevicius' peaks at "kin care," one of the final tasks that 
humans engage in to make sure that their genes outlive them. Leading up to kin care are the evolved needs for self-protection, disease avoidance, affiliation, status, mate acquisition, and mate retention, in order of developmental emergence. Although all of these "subselves" often co-occur with one another, individuals have to wait for either shorter or longer stretches of time before each comes to the fore, and some subselves may never manifest at all. So, for example, although our need for self-protection develops fairly early (e.g., even infants are wary of strangers; Sroufe 1977), it is not until we have children of our own that our kin care subself emerges.

The emergence of each of the subselves is dependent on the vagaries of an individual's predisposition and the timing of their exposure to specific problems of survival and reproduction. It is likely that the different mechanisms of transcendence track this and vary across individuals in the timing of their emergence. Note also that, although transcendent experiences are prevalent even in industrialized nations, the majority of people simply do not experience such states of consciousness. This fact does not dismiss the adaptive nature of these states, just as the fact that there are two sexes does not negate the evolved value of either males or females - some adaptations are only found in some individuals because others make use of different means by which to get their genes into the ensuing generation.

Using Kenrick and Griskevicius' developmental framework, I predict that certain types of transcendent experiences are more likely than others at each life stage. Early childhood, for example, will likely be the stage at which supernatural experiences take precedence. Regardless of whether such experiences are transcendent, Kelemen (2004) suggests that children are, in fact, naturally predisposed to theism. This is not to say that children are born believing in Yahweh, Christ, or Allah; rather, their automatic attribution of mental properties to inanimate objects and occurrences (e.g., thoughtful clouds, happy trees, etc.) may either be a necessary by-product of a developing ToM or an adaptation that either helped our ancestors to avoid predators or endear themselves to caregivers during childhood (Bjorklund et al. 2010).

It is also likely that, given children's reliance on parents as their primary caregivers early on in life, the need for selfprotection - the first developmental stage along Kenrick and Grikevicius' evolved developmental trajectory-may coincide with the attribution of parental properties to incorporeal entities such as gods and spirits. Such attributions may reflect the adaptive importance of children's moral development and the reliance on supernatural threats and incentives for the subsequent formation and retention of affiliative ties to othersKenrick and Griskevicius' third developmental stage. This stage is activated throughout the lifespan-from preschool to old age. It is during this stage that another type of transcendent experience occurs - one whose evolved function is the formation of coalitional ties to other individuals. This is usually accomplished by costly material and emotional signals, as previously discussed. Although children have reported quite intense spiritual and mystical states (Tamminen 1994), such friendship and group-solidifying emotions occur mostly in adolescence and young adulthood (see Atran 2002, pp. 166-169).

In societies that interpret such group-directed transcendent states in supernatural terms, they are often undergirded by the attribution of mental states to incorporeal beings - beings who may enforce ingroup cooperation and function as the intermediaries between individuals of the same coalition. Sometimes, group-directed transcendence may be coincidental with an individual's experience of sexual attraction or falling in love-states coinciding with the coming of Kenrick and Griskevicius' mate acquisition, mate retention, and kin care subselves. It is this type of transcendent experience that may have inspired the pervasive linkage between the religious and the romantic. Likewise, the group-oriented transcendent state may coincide with epistemic states that contribute to the immersive aspects of the experience-e.g., the aforementioned epistemic dissolution of the self in favor of a higher, group-directed cause among Zen-inspired Kamikaze pilots.

Assuming that creativity and intellectual production are, in part, sexually selected skills (Miller 1999), we can expect aesthetic and epistemic transcendence to be more prevalent among individuals in the prime of their reproductive years (though it should not be restricted to them). These are individuals who can capitalize on this type of transcendence if it helps them to produce creative artworks or intellectual and practical discoveries - signals that communicate their reproductive value. As Kenrick and Griskevicus write, "We do not deny that human beings are motivated to be creative and artistic. But a desire to self-actualize is not detached from our social goals ...” (p. 44). Thus, Maslow's ultimate stage of healthy maturation - punctuated by the prevalence of transcendent states that Maslow referred to as "peak experiences" (Maslow 1964) - may be salvaged as an important proximate means toward the evolved ends of survival and reproduction.

The developmental journey of the organism should be no surprise to devotees of transcendent experiences. The spiritual or transcendent life is often described as a "journey" or "path." The mythical tale of Gautama's (i.e., the Buddha's) coming to enlightenment is a developmental tale consisting of stages along which Gautama is gradually made aware of old age, disease, and death - a journey whose ultimate lesson is impermanence, to which the remedy is following the "middle way" (a compromise between attachment to the world and its negation). Indeed, the developmental timeline may itself function as the instigator of transcendent states. The process of psychological development is a dynamic one that is marked by the gradual emergence of evolved psychological states, or modules, and this emergence depends on the 
complex web of interactions between the genetic and nongenetic environment. Likewise, modules interact with other modules across the lifespan, sometimes vying for control, other times awaiting their turn to get activated either during specific life stages (e.g., puberty) or when facing specific problems of survival and reproduction (e.g., finding friends and mates). The appearance of latent modules-i.e., complex psychological structures that individuals are not even aware of possessing, such as the evolved psychological systems that motivate parenting - may itself be associated with an immersive transcendent state at any point during the lifespan. If such development-induced transcendent states occur, it is still a question as to whether they are co-opted by natural selection to aid in survival and reproduction or whether they are the non-adaptive byproducts of ontogeny.

\section{The Liberation of Transcendence from Exploitation}

At worst, the transcendent experience manifests an illusory view of reality that is then exploited by manipulators. Yet, for such a hard-to-define experience, its pervasiveness in our species compels us to acknowledge both its pitfalls and its utility. There are two questions that must be answered when considering transcendent experiences: (1) how much do they reflect reality and (2) what are their ethical implications?

The vulnerability of the transcendent experience to exploitation suggests that its truth value is bleak. How can we ever arrive at an honest account of reality via transcendence if we so easily fall prey to selfish manipulators who activate our ingroup-directed emotions and beliefs in non-existent supernatural agents, or are so easily influenced by exploitative beauty and illusory knowledge? Even where there are no manipulators, the evolutionary origin of transcendence does not ensure its accuracy as a model of reality - much like our visual and auditory systems sometimes misrepresent our world, as highlighted by our vulnerability to visual and auditory illusions. Nevertheless, given that even sober states of reality can be illusory, something must be said in favor of the transcendent state and its ontological connotations. After all, however flawed our visual and auditory systems are, they enable us to more or less successfully navigate our world. Similarly, as flawed and vulnerable to exploitation as our multiple modes of transcendence are, we should not write off their epistemic utility so quickly.

The skeptic will demur that evidence, logic, and reason are the most trustworthy means of acquiring the truth. But is this always true? In their article on the evolutionary advantage of reason, Mercier and Sperber (2011) advanced the hypothesis that reason evolved because it enabled our argumentative ancestors to successfully convince others of some point of view or course of action, and to thereby advance their (i.e., the arguers') prestige - and, hence, reproductive success. If someone can utilize seemingly coherent arguments, then that person should be believed. The advantage to the recipient of such reasoned messages is the presumed validity of the messages i.e., on average, individuals who employed reasoned argument were more likely to communicate useful, if not truthful, information. The selective advantage of reason, however, came with a cost to those who would be duped by it into following a seemingly intelligent — albeit manipulativesophist. Thus, far from being instances of flawed reasoning, phenomena such as the hindsight bias and the confirmation bias are reason's main features. If so, then the concept of "truth" seems to be in question. Is truth completely reliant on evidence, logic, and reason, or is it something that is beyond one or another conceptual explanation?

There is something to be said for occasionally shutting off all of the distractions that bombard the individual in modern society. From the automatic siphoning of one's attention to radio and satellite signals, to the everyday commitments to one's family, friends, and society at large, our environments are overflowing with manipulative influences. By engaging in meditation or some other transcendence-inducing practice, perhaps individuals can avoid being swayed by toothpaste advertisements and political propaganda (note Davidson and Lutz's 2008, discussion of meditation's efficacy in promoting attention and reducing distraction). As recounted by Huxley in The Perennial Philosophy (1970/1945; pp. 125-146), mystics from a variety of religious traditions and historical epochs were skeptical of the power of language and reason to communicate certain truths that can only be revealed by a direct encounter with what Buddhists call tathātā or "suchness." I would counter that the apparent opposition between reason and more intuitive forms of knowing is a false dichotomy. Assuming that the ability to reason was selected because it enabled our ancestors to win arguments, the utility of transcendent experiences may be their capacity to dissolve illusory arguments, words, and appearances. Such a dissolving effect may, in turn, prepare the mind for the acceptance of better, more truthful forms of knowledge, be it in the form of nonexploitative arguments or experiences of suchness. Alongside self-correcting institutions based on peer review and the dialectic process, perhaps transcendent states might help us to drill down to some deeper truth hidden beneath the veneer of our evolutionarily limited everyday sensory experience. The revelations derived from such transcendent states should not be viewed as substitutes for evidence and reason, but as forms of knowledge that complement reason by clearing the fallacious residue surrounding it and supplement it by revealing states of consciousness beyond the humdrum of everyday experience. For example, the self-dissolving aspect of transcendence is supported by neuroscientific and psychological research on the absence of an encapsulated, unitary self (Kurzban 2010). The multidimensional nature of 
psychological selfhood, discovered by ancient mystics and contemplatives, is therefore a more accurate model of the mind than the Cartesian dualism still influencing academic philosophy (Dennett 1991, pp. 101-138).

As for the ethical implications of transcendence, the previously discussed anthropological and ethnographic record suggests that transcendent states trigger empathic identification with one's fellow tribe members and promote ingroup cohesion via emotional and material commitments. The problem, however, is that, historically, such transcendent states were limited to only inspiring fellow-feeling directed at one's ingroup. This is especially highlighted by the use of transcendence to inspire martial cohesion and the readiness to sacrifice oneself for one's brothers-in-arms and ingroup at large during times of warfare (MacNeill 2004). As such, we should be cautious whenever political or religious leaders evoke transcendence to inspire social cohesion. Nevertheless, if groupdirected transcendence can be evoked in a global society wherein members view all of humanity - and perhaps all sentient beings - as part of their ingroup, transcendence might be salvaged as an invaluable tool for creating and maintaining peace and well-being.

\section{References}

Apicella, C. L., Little, A. C., \& Marlowe, F. W. (2007). Facial averageness and attractiveness in an isolated population of hunter-gatherers. Perception, 36, 1813-1820.

Atran, S. (2002). In gods we trust: the evolutionary landscape of religion. New York: Oxford University Press.

Austin, M. R. (1980). Aesthetic experience and the nature of religious perception. The Journal of Aesthetic Education, 14, 19-35.

Babkoff, H., Sing, H. C., Thorne, D. R., Genser, S. G., \& Hegge, F. W. (1989). Perceptual distortions and hallucinations reported during the course of sleep deprivation. Perceptual and Motor Skills, 68, 787-789.

Barnett, H. G. (1938). The nature of the potlatch. American Anthropologist, 40, 349-358.

Baron-Cohen, S. (2005). The empathizing system: a revision of the 1994 model of the mindreading system. In B. J. Ellis \& D. F. Bjorklund (Eds.), Origins of the social mind: evolutionary psychology and child development (pp. 468-492). New York: Guilford.

Baron-Cohen, S., Leslie, A. M., \& Frith, U. (1985). Does the autistic child have a "theory of mind"? Cognition, 21, 37-46.

Barrett, J. L. (2000). Exploring the natural foundations of religion. Trends in Cognitive Sciences, 4, 29-34.

Bjorklund, D. F., Blasi, C. H., \& Periss, V. A. (2010). Lorenz revisited: the adaptive nature of children's supernatural thinking. Human Nature, 21, 371-392.

Borchert, B. (1994). Mysticism: it's history and challenge. York Beach: Weiser.

Botelho, J. B., \& Weigel, V. A. (2011). The sateré-mawé community of Y'Apyrehyt: ritual and health on the urban outskirts of Manaus. História, Ciências, Saúde Manguinhos, 18, 723-744.

Brown, L. A. (2005). Planting the bones: hunting ceremonialism at contemporary and nineteenth-century shrines in the Guatemalan highlands. Latin American Antiquity, 16(2), 131-146.
Buckner, R. L., Andrews-Hanna, J. R., \& Schacter, D. L. (2008). The brain's default network: anatomy, function, and relevance to disease. The Year in Cognitive Neuroscience, 1124, 1-38.

Caldwell, C. A., \& Millen, A. E. (2008). Experimental models for testing hypotheses about cumulative cultural evolution. Evolution and Human Behavior, 29(3), 165-171.

Carhart-Harris, R. L., Erritzoe, D., Williams, T., Stone, J. M., Reed, L. J., Colasanti, A., Nutt, D. J. (2012). Neural correlates of the psychedelic state as determined by fMRI studies with psilocybin. Proceedings of the National Academy of Science, 109, 2138-2143.

Carter, C. S., Braver, T. S., Barch, D. M., Botvinick, M. M., Noll, D., \& Cohen, J. D. (1998). Anterior cingulate cortex, error detection, and the online monitoring of performance. Science, 280, 747-749.

Chartrand, T. L., \& Bargh, J. A. (1999). The chameleon effect: the perception-behavior link and social interaction. Journal of Personality and Social Psychology, 76, 893-910.

Chelnokova, O., Laeng, B., Eikemo, M., Riegels, J., Løseth, G., Maurud, H.,...Leknes, S. (2014). Rewards of beauty: the opioid system mediates social motivation in humans. Molecular Psychiatry, 19, 746-747.

Cosmides, L., \& Tooby, J. (1992). Cognitive adaptations for social exchange. In J. Barkow, L. Cosmides, \& J. Tooby (Eds.), The adapted mind: evolutionary psychology and the generation of culture (pp. 163-228). New York: Oxford University Press.

Criss, M. M., Shaw, D. S., \& Ingoldsby, E. M. (2003). Mother-son positive synchrony in middle childhood: relation to antisocial behavior. Social Development, 12, 379-400.

Cronk, L. (1994). Evolutionary theories of morality and the manipulative use of signals. Zygon, 29, 81-101.

Csikszentmihalyi, M., \& Nakamura, J. (2002). The concept of flow. In C. R. Snyder \& S. J. Lopez (Eds.), Handbook of positive psychology (pp. 89-105). New York: Oxford University Press.

Darwin, C. (2006/1871). The descent of man, and selection in relation to sex. In E. O. Wilson (Ed.), From so simple a beginning: The four great books of Charles Darwin (pp. 767-1248). New York: Norton.

Davidson, R. J., \& Lutz, A. (2008). Buddha's brain: neuroplasticity and meditation. IEEE Signal Processing Magazine, 25, 176-176.

Dawkins, R. (1976). The selfish gene. Oxford: Oxford University Press.

Dawkins, R. (1982). The extended phenotype. Oxford: Oxford University Press.

Dawkins, R., \& Krebs, J. R. (1979). Arms races between and within species. Proceedings of the Royal Society of London: Biology, 205, 489-511.

Dennett, D. (1987). The intentional stance. Cambridge: MIT Press.

Dennett, D. (1991). Consciousness explained. Boston: Little, Brown \& Co.

Dutton, D. (2003). Aesthetics and evolutionary psychology. In J. Levinson (Ed.), The Oxford handbook of aesthetics (pp. 693-705). New York: Oxford University Press.

Feldman, R. (2007). Parent-infant synchrony and the construction of shared timing; physiological precursors, developmental outcomes, and risk conditions. Journal of Child Psychology and Psychiatry, 48, 329-354.

Feldman, R., \& Greenbaum, C. W. (1997). Affect regulation and synchrony in mother-infant play as precursors to the development of symbolic competence. Infant Mental Health Journal, 18, 4-23.

Feldman, R., Greenbaum, C. W., \& Yirmiya, N. (1999). Mother-infant affect synchrony as an antecedent of the emergence of self-control. Developmental Psychology, 35, 223-231.

Fink, B., Grammer, K., \& Thornhill, R. (2001). Human (Homo sapiens) facial attractiveness in relation to skin texture and color. Journal of Comparative Psychology, 115, 92-99.

Freud, S. (1919). Totem and taboo: resemblances between the psychic lives of savages and neurotics. London: Butler \& Tanner.

Gangestad, S. W., Thornhill, R., \& Yeo, R. A. (1994). Facial attractiveness, developmental stability, and fluctuating asymmetry. Ethology and Sociobiology, 15(2), 73-85. 
Ginges, J., Hansen, I., \& Norenzayan, A. (2009). Religion and support for suicide attacks. Psychological Science, 20, 224-230.

Granqvist, P., \& Kirkpatrick, L. A. (2004). Religious conversion and perceived childhood attachment: a meta-analysis. The International Journal for the Psychology of Religion, 14, 223-250.

Grob, C. S., Danforth, A. L., Chopra, G. S., Hagerty, M., McKay, C. R., Halberstadt, A. L., \& Greer, G. R. (2011). Pilot study of psilocybin treatment for anxiety in patients with advanced-stage cancer. Archives of General Psychiatry, 68, 71-78.

Gueguen, N. (2009). Mimicry and seduction: an evaluation in a courtship context. Social Influence, 4, 249-255.

Guruge, A. W. (1997). The Buddha's encounters with Māra the Tempter. Kandy: Buddhist Publication Society.

Haidt, J. (2012). The righteous mind: why good people are divided by politics and religion. New York: Pantheon Books.

Harding, C. (2014). Into nothingness. Aeon. Retrieved from https://aeon. co/essays/the-zen-ideas-that-propelled-japan-s-young-kamikazepilots

Harris, S. (2014). Waking up. New York: Simon \& Schuster.

Harris, S., Kaplan, J. T., Curiel, A., Bookheimer, S. Y., Iacoboni, M., \& Cohen, M. S. (2009). The neural correlates of religious and nonreligious belief. PLOS ONE, 4, e7272.

Haselton, M. G., \& Buss, D. M. (2000). Error management theory: a new perspective on biases in cross-sex mind reading. Journal of Personality and Social Psychology, 78(1), 81-91.

Hori, V. S. (2004). The book of capping phrases for kōan practice. Honolulu: University of Hawaii Press.

Hume, D. (1978/1739). A treatise of human nature (2nd ed.). Oxford: Oxford University Press.

Huron, D. (2001). Is music an evolutionary adaptation? Annals of the New York Academy of Sciences, 930, 43-61.

Huxley, A. (1970/1945). The perennial philosophy. New York: Harper \& Row.

James, W. (2004/1902). The varieties of religious experience. New York: Barnes \& Noble Classics.

Kapogiannis, D., Barbey, A. K., Su, M., Krueger, F., \& Grafman, J. (2009). Neuroanatomical variability of religiosity. PLoS ONE, 4, e7180.

Kelemen, D. (2004). Are children "intuitive theists"? Reasoning about purpose and design in nature. Psychological Science, 15, 295-301.

Keller, M. C., \& Nesse, R. M. (2006). The evolutionary significance of low mood symptoms. Journal of Personality and Social Psychology, 91, 316-330.

Kenrick, D. T., \& Griskevicius, V. (2013). The rational animal: how evolution made us smarter than we think. New York: Basic Books.

Kirkpatrick, L. A. (2005). Attachment, evolution, and the psychology of religion. New York: Guilford Press.

Kirkpatrick, L. A., \& Shaver, P. R. (1992). An attachment-theoretical approach to romantic love and religious belief. Personality and Social Psychology Bulletin, 18, 266-275.

Kulisevsky, J., Pagonabarraga, J., \& Martinez-Corral, M. (2009). Changes in artistic style and behavior in Parkinson's disease: dopamine and creativity. Journal of Neurology, 256, 816-819.

Kurzban, R. (2010). Why everyone (else) is a hypocrite. Princeton: Princeton University Press.

Lakin, J. L., Jefferis, V. E., Cheng, C. M., \& Chartrand, T. L. (2003). The chameleon effect as social glue: evidence for the evolutionary significance of nonconscious mimicry. Journal of Nonverbal Behavior, $27,145-162$.

Launay, J., Dean, R. T., \& Bailes, F. (2014). Synchronising movements with the sounds of a virtual partner enhances partner likeability. Cognitive Processing, 15, 491-501.

Leary, T., Metzner, R., \& Albpert, R. (2000/1964). The psychedelic experience: A manual based on the Tibetan book of the dead. New York: Citadel Press.

Levin, J., \& Steele, L. (2005). The transcendent experience: conceptual, theoretical, and epidemiologic perspectives. Explore, 1, 89-101.
Levitin, D. J., \& Menon, V. (2003). Musical structure is processed in "language" areas of the brain: a possible role for Brodmann area 47 in temporal coherence. NeuroImage, 20, 2142-2152.

Lewkowicz, D. J., \& Ghazanfar, A. A. (2009). The emergence of multisensory systems through perceptual narrowing. Trends in Cognitive Science, 13, 470-478.

Liu, Y., \& Wang, Z. X. (2003). Nucleus accumbens oxytocin and dopamine interact to regulate pair bond formation in female prairie voles. Neuroscience, 121, 537-544.

MacNeill, A. (2004). The capacity for religious experience is an evolutionary adaptation to warfare. Evolution and Cognition, 10, 43-60.

Mars, R. B., Neubert, F., Noonan, M. P., Sallet, J., Toni, I., \& Rushworth, M. F. (2012). On the relationship between the "default mode network" and the "social brain". Frontiers in Human Neuroscience, 6, 1-9.

Maslow, A. H. (1964). Religions, values, and peak experiences. Colombus: Ohio State University Press.

Meltzoff, A. N., \& Decety, J. (2003). What imitation tells us about social cognition: a rapprochement between developmental psychology and cognitive neuroscience. Philosophical Transactions of the Royla Socity of London: Biological Science, 358, 491-500.

Mercier, H., \& Sperber, D. (2011). Why do humans reason? Arguments for an argumentative theory. Behavioral and Brain Sciences, 34, 57-111.

Miller, G. F. (1999). Sexual selection for cultural displays. In R. Dunbar, C. Knight, \& C. Power (Eds.), The evolution of culture (pp. 71-91). Edinburgh: Edinburgh University Press.

Miller, G. F. (2000). Evolution of human music through sexual selection. In N. L. Wallin, B. Merker, \& S. Brown (Eds.), The origins of music (pp. 329-360). Cambridge: MIT Press.

Müller, C. P., \& Schumann, G. (2011). Drugs as instruments: a new framework for non addictive psychoactive drug use. Behavioral and Brain Sciences, 34, 293-347.

Newton, J. (2014). Hitler's call to arms: how the Fuhrer had a photographer help him practice his extreme hand gestures and body language. Daily Mail. Retrieved from http:/www.dailymail.co.uk/ news/article-2679618/Hitlers-call-arms-How-Fuhrer-photographerhelp-practice-extreme-hand-gestures-body-language.html

Norenzayan, A., Shariff, A. F., Gervais, W. M., Willard, A., McNamara, R., Slingerland, E., \& Henrich, J. (2014). The cultural evolution of prosocial religions. Behavioral and brain sciences. 1-86 doi10. 1017/S0140525X14001356, e0

Odling-Smee, J., Laland, K., \& Feldman, M. (2003). Niche construction: the neglected process in evolution. Princeton: Princeton University Press.

Oehen, P., Traber, R., Widmer, V., \& Schnyder, U. (2013). A randomized, controlled pilot study of MDMA $( \pm 3,4-$ methylenedioxymethamphetamine)-assisted psychotherapy for the treatment of resistant, chronic post-traumatic stress disorder (PTSD). Journal of Psychopharmacology, 27, 40-52.

Otmakhova, N. A., \& Lisman, J. E. (1996). D1/D5 dopamine receptor activation increases the magnitude of early long-term potentiation at CA1 hippocampal synapses. The Journal of Neuroscience, 16, $7478-7486$.

Pardo, J. V., Pardo, P. J., Janer, K. W., \& Raichle, M. E. (1990). The anterior cingulate cortex mediates processing selection in the Stroop attentional confllict paradigm. Proceedings of the National Academy of Science, 87, 256-259.

Pinchbeck, D. (2002). Breaking open the head: a psychedelic journey into the heart of contemporary shamanism. New York: Broadway Books.

Pinker, S. (1997). How the mind works. New York: Norton.

Rapinsky-Naxon, M. (1993). The nature of shamanism: substance and function of a religious metaphor. Albany: State University of New York Press.

Rivier, L., \& Lindgren, J. E. (1972). "Ayahuasca," the South American hallucinogenic drink: an ethnobotanical and chemical investigation. Economic Botany, 26, 101-129. 
Rocha, T. (2014). The dark knight of the soul. The Atlantic. Retrieved from http://www.theatlantic.com/health/archive/2014/06/the-darkknight-of-the-souls/372766/

Salimpoor, V. N., Benovoy, M., Larcher, K., Dagher, A., \& Zatorre, R. J. (2011). Anatomically distinct dopamine release during anticipation and experience of peak emotion to music. Nature Neuroscience, 14 , 257-262.

Sharf, R. H. (1993). The Zen of Japanese nationalism. History of Religions, 33, 1-43.

Sluhovsky, M. (2002). The devil in the convent. The American Historical Review, 107, 1379-1411.

Sosis, R., \& Alcorta, C. (2003). Signaling, solidarity, and the sacred: the evolution of religious behavior. Evolutionary Anthropology, 12, 264-274.

Sosis, R., \& Bressler, E. R. (2003). Cooperation and commune longevity: a test of the costly signaling theory of religion. Cross-Cultural Research, 37, 211-239.

Sroufe, L. A. (1977). Wariness of strangers and the study of infant development. Child Development, 48, 731-746.

Staff. (2012). Teenage monk sets himself on fire on 53rd anniversary of failed Tibetan uprising. The Telegraph. Retrieved from http://www. telegraph.co.uk/news/worldnews/asia/tibet/9139760/Teenagemonk-sets-himself-on-fire-on-53rd-anniversary-of-failed-Tibetanuprising.html

Suddendorf, T., \& Corballis, M. C. (2007). The evolution of foresight: what is mental time travel, and is it unique to humans? Behavioral and Brain Sciences, 30, 299-313.

Tamminen, K. (1994). Religious experiences in childhood and adolescence: a viewpoint of religious development between the ages of 7 and 20. The International Journal for the Psychology of Religion, 4, $61-85$.

Teresa of Avila, S. (1904). The life of St. Teresa of Jesus, of the order of Our Lady of Carmel. London: Thomas Baker.

Trivers, R. L. (1972). Parental investment and sexual selection. In B. Campbell (Ed.), Sexual selection and the descent of man, 18711971 (pp. 136-179). Chicago: Aldine-Atherton.

Vallacher, R. R. (2009). Self: the unity of self, self-consistency. In W. P. Banks (Ed.), Encyclopedia of consciousness (Vol. 2) (pp. 313-325). Oxford: Elsevier.
Vallacher, R. R., \& Wegner, D. M. (2012). Action identification theory. In P. A. Lange, A. W. Kruglanski, \& E. T. Higgins (Eds.), Handbook of theories of social psychology (pp. 327-348). Thousand Oaks: Sage.

van Straaten, I., Engels, C. M., Finkenauer, C., \& Holland, R. W. (2008). Sex differences in short-term mate preferences and behavioral mimicry: a semi-naturalistic experiment. Archives of Sexual Behavior, 37, 902-911.

Varela, F., Lachaux, J. P., Rodriguez, E., \& Martinerie, J. (2001). The brainweb: phase synchronization and large-scale integration. National Review of Neuroscience, 2, 229-239.

von Hippel, W., \& Trivers, R. (2011). The evolution and psychology of self-deception. Behavioral and Brain Sciences, 34, 1-56.

Waida, M. (1983). Problems of central Asian and Siberian shamanism. Numen, 30, 215-239.

Waxman, S. G., \& Geschwind, N. (1975). The interictal behavior syndrome of temporal lobe epilepsy. Archives of General Psychiatry, $32,1580-1586$.

Wedekind, C., Seebeck, T., Bettens, F., \& Paepke, A. J. (1995). MHCdependent mate preferences in humans. Proceedings of the Royal Society of London: Biological Sciences, 260, 245-249.

Wells, D. A. (2015). The extended phenotype(s): a comparison with niche construction theory. Biology \& Philosophy, 30, 547-567.

Wilkins, L. K., Girard, T. A., \& Cheyne, J. A. (2011). Ketamine as a primary predictor of out-of-body experiences associated with multiple substance use. Consciousness and Cognition, 20, 943-950.

Wilson, D. S. (2002). Darwin's cathedral: evolution, religion, and the nature of society. Chicago: University of Chicago Press.

Wilson, C. G. (2008). Male genital mutilation: an adaptation to sexual conflict. Evolution \& Human Behavior, 29, 149-164.

Winegard, B. M., Reynolds, T., Baumeister, R. F., Winegard, B., \& Maner, J. K. (2014). Grief functions as an honest indicator of commitment. Personality and Social Psychology Review, 18, 168-186.

Wright, R. (2009). The evolution of god. New York: Little, Brown and Company.

Wyman, B. (1999). Woodstock 99: Three days of peace, love and rape. Salon. Retrieved from http://www.salon.com/1999/07/29/rape_4/

Zahavi, A. (1975). Mate selection: a selection for a handicap. Journal of Theoretical Biology, 53, 205-214. 